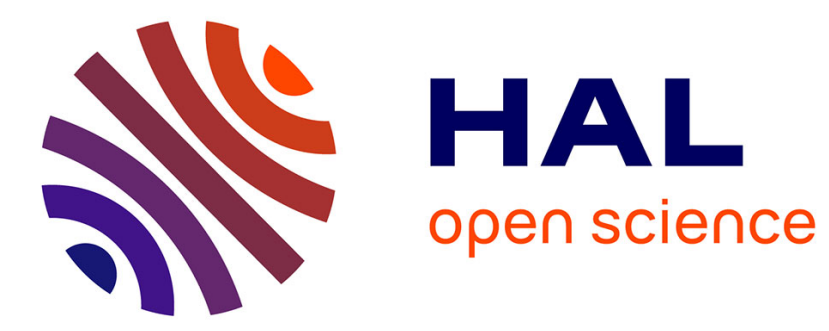

\title{
Chronoamperometric Investigations of the Electrode-Electrolyte Interface of a Commercial High Temperature PEM Fuel Cell
}

Ashish Kamat, Andreas Huth, Olaf Klein, Stephan Scholl

\section{To cite this version:}

Ashish Kamat, Andreas Huth, Olaf Klein, Stephan Scholl. Chronoamperometric Investigations of the Electrode-Electrolyte Interface of a Commercial High Temperature PEM Fuel Cell. Fuel Cells, 2010, 10 (6), pp.983. 10.1002/fuce.201000014 . hal-00577277

\section{HAL Id: hal-00577277 \\ https://hal.science/hal-00577277}

Submitted on 17 Mar 2011

HAL is a multi-disciplinary open access archive for the deposit and dissemination of scientific research documents, whether they are published or not. The documents may come from teaching and research institutions in France or abroad, or from public or private research centers.
L'archive ouverte pluridisciplinaire HAL, est destinée au dépôt et à la diffusion de documents scientifiques de niveau recherche, publiés ou non, émanant des établissements d'enseignement et de recherche français ou étrangers, des laboratoires publics ou privés. 


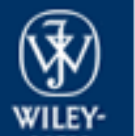

Fuel Cells

VCH

\section{Chronoamperometric Investigations of the Electrode- Electrolyte Interface of a Commercial High Temperature PEM Fuel Cell}

\begin{tabular}{|c|c|}
\hline Journal: & Fuel Cells \\
\hline Manuscript ID: & fuce. $201000014 . R 2$ \\
\hline Wiley - Manuscript type: & Original Research Paper \\
\hline $\begin{array}{l}\text { Date Submitted by the } \\
\text { Author: }\end{array}$ & 28-Jun-2010 \\
\hline Complete List of Authors: & $\begin{array}{l}\text { Kamat, Ashish; Volkswagen AG, Group Research Fuel Cell; } \\
\text { Technische Universität Braunschweig, Institut für Chemische und } \\
\text { Thermische Verfahrenstechnik } \\
\text { Huth, Andreas; Volkswagen AG, Group Research Fuel Cell } \\
\text { Klein, Olaf; Volkswagen AG, Group Research Fuel Cell } \\
\text { Scholl, Stephan; Technische Universität Braunschweig, Institut für } \\
\text { Chemische und Thermische Verfahrenstechnik }\end{array}$ \\
\hline Keywords: & $\begin{array}{l}\text { Diffusive Mass Transport, Gas Diffusion Electrode (GDE), Interface, } \\
\text { Mass Transport, Mathematical Simulation, MEA, Performance }\end{array}$ \\
\hline
\end{tabular}

\section{scholarONE" \\ Manuscript Central}




\title{
Chronoamperometric Investigations of the Electrode-Electrolyte Interface of a Commercial High Temperature PEM Fuel Cell
}

\author{
A. Kamat ${ }^{12^{*}}$, A. Huth ${ }^{1}$, O. Klein ${ }^{1}$, S. Scholl ${ }^{2}$ \\ ${ }^{1}$ Group Research Fuel Cell, Volkswagen AG, Letter Box 011/1172, 38436 Wolfsburg, Germany \\ ${ }^{2}$ Institut für Chemische und Thermische Verfahrenstechnik, T. U. Braunschweig, Langer Kamp 7, \\ 38106 Braunschweig, Germany
}

\section{[*] Corresponding Author, ashish.kamat@volkswagen.de}

\begin{abstract}
This paper presents investigations into the chronoamperometric experiments performed on polybenzimidazole (PBI) / phosphoric acid based high temperature polymer electrolyte membrane fuel cells (HT-PEM FC). Electrolyte loadings in the membrane electrode assembly (MEA) are varied to realize three different degrees of flooding of the electrode. Steady state as well as dynamic measurements at three different temperatures $\left(160^{\circ} \mathrm{C}\right.$, $120^{\circ} \mathrm{C}$ and $80^{\circ} \mathrm{C}$ ) is made via chronoamperometry on these cells. The transient current behavior resulting from a voltage step change from open circuit voltage $(\sim 1 \mathrm{~V})$ to low voltages $(0.1 \mathrm{~V})$ are recorded and analyzed. Analysis using the Cottrell plot depicts the underlying mass transport processes in the three different electrodes, catalyst utilization as well as a better description of the three phase boundary reaction zone. An extension of the Cottrell equation is deduced to describe a regular commercial fuel cell behavior.
\end{abstract}

Keywords: Chronoamperometry, Cottrell, Diffusion Limiting Current, PBI, Phosphoric Acid

\section{Introduction}

Polymer electrolyte membrane (PEM) fuel cells are one of the most promising candidates for powering transportation systems. Fuel cell driven cars are already being introduced on the road and undergoing final stages of testing and development [1--4]. The high temperature PBI / phosphoric acid PEM fuel cell has some operational advantages (no humidification, higher $\mathrm{CO}$ tolerance) over the low temperature Nafion $®$ based PEM fuel cell. Nevertheless, in comparison, the HT-PEM fuel cell has lower cell current densities. This is largely due to the presence of phosphoric acid in the electrode-electrolyte interface. Limited permeability of oxygen in phosphoric acid medium and the influence of the adsorbed phosphate species on oxygen reduction reaction (ORR) kinetics are identified as the limiting factors [5].

The electrode-electrolyte interface behavior in a commercial HT-PEM fuel cell largely determines its performance. The attempt to describe this interface is often done via a three phase boundary model, where it is assumed that there exists a physical contact area between the solid $\mathrm{Pt} / \mathrm{C}$ electrode particles, the liquid electrolyte and the gas phase [5]. The hydrogen oxidation reaction (HOR) is faster than the ORR and hence the anode side over-potentials are often safely neglected for modeling purposes [6]. On the cathode side, the oxygen permeability in phosphoric acid is at least an order of magnitude lower than in Nafion $® /$ water electrolyte. Mass transport investigations in commercial cells are rarely carried out due to larger inaccuracy of the diffusion and solubility parameters. Most research focuses on small well-defined electrodes, which can be useful in precisely determining the mass transport parameters, but cannot clearly describe the complex processes in a commercial cell [7--10]. Mass transport investigations via chronoamperometry are often reported in literature as well as their analysis using Cottrell or Cottrell-like equations [11,12]. This approach is revisited to arrive at useful techniques to better understand the processes occurring at the electrode-electrolyte interface of a commercial fuel cell.

\section{Theoretical Background}

Chronoamperometry is an established method where the test cell is subjected to a voltage step change and the transient response from the cell current is recorded. In order to study the diffusion processes, the transient current in the mass transport limitation region of the polarization curve is of higher relevance. To accomplish this, the cell voltage is stepped down from open circuit voltage (OCV) to lower than $0.2 \mathrm{~V}$. The corresponding transient cell current can be described by the following equation,

$$
i_{\text {cell }}=i_{d}+i_{\text {cap }}
$$

where $i_{\text {cell }}$ is the total cell current, $i_{d}$ is the diffusion limiting current and $i_{\text {cap }}$ is the capacitive current. This study uses the chronoamperometric experiments and the Cottrell experiment and equation to assemble the experimental setup and analyze the experimental results [13]. The Cottrell equation for diffusion limiting current is 
where $n$ is the number of electrons transferred in one electrochemical reaction step, $F$ is the Faraday constant, $A$ is the active electrode area, $D$ is the diffusion coefficient of oxygen in electrolyte, $C^{*}$ is the initial bulk concentration of oxygen in electrolyte and $t$ is the time. This equation is valid for a planar electrode in an unstirred electrolyte solution. This transient current when plotted against the inverse square root of time (Cottrell plot) depicts a straight line heading towards the origin.

In case of a spherical electrode, the Cottrell equation can be extended to

$i_{d}(t)=\frac{n F A D_{O_{2}}^{1 / 2} C_{O_{2}}^{*}}{\pi^{1 / 2} t^{1 / 2}}+\frac{n F A D_{O_{2}} C_{O_{2}}^{*}}{\delta}$

where the time independent second term includes " $\delta$ " which is the radius of the spherical electrode. Its Cottrell plot is a straight line intercepting the cell current axis.

For short times $(\mathrm{t}<0.1 \mathrm{~s})$ the capacitive current is a considerable contribution to the total cell current and can be described by the equation

$$
i_{\text {cap }}(t)=\frac{E}{R_{u}} \exp \left(\frac{-t}{R_{u} C_{d}}\right)
$$

where $E$ is the magnitude of the cell voltage step, $R_{u}$ is the uncompensated resistance, $C_{d}$ is the double layer capacitance and $t$ is the time. At times greater than 0.1 seconds, this contribution however is almost negligible. This is largely due to the exponential decay in the capacitive current with a cell time constant (product of uncompensated resistance and double layer capacitance) [13]. Measured current data at time intervals approximately 10 times larger than the cell time constant are considered to be reliable measurement points for the diffusion limiting cell current $i_{d}$.

\section{Experimental}

The experimental setup consists of test cells mounted on fuel cell test benches C100 from FuelCon AG. The fuel cell hardware comprises of two metal alloy blocks that provide connections for fuel flow inlets and outlets, temperature and voltage sensors as well as the current collector plates. The inner side of this block holds a graphite plate with square shaped flow field in the center exhibiting flow channels of serpentine design. The total area of the flow field approximates $10 \mathrm{~cm}^{2}$. The $\mathrm{Pt} / \mathrm{C}$ electrode paste is prepared in house and printed on the GDL material and has a combined thickness of $300 \mu \mathrm{m}$. Both the anode and cathode are identically prepared with estimated platinum loading of $1.5 \mathrm{mg} \mathrm{cm}^{-2}$. The dry PBI membrane is doped with $85 \%$ phosphoric acid and has an impregnated thickness of around $50 \mu \mathrm{m}$. This membrane is sandwiched between the electrodes. For structural integrity of the MEA, two extra components are used. A thin film of about $25 \mu \mathrm{m}$ made of insulating Kapton material is used to hold the membrane in place. The MEA is then set between two polytetrafluroethylene (PTFE) sealings. These films are about $200 \mu \mathrm{m}$ thick and also provide electrical insulation along with impermeability to reactant gases. The fuel cell hardware blocks on either side of the MEA are screwed together. The test cell is then mounted on the test bench, which provides operational support.

The C100 test bench has connections for gas supply, heating rods, temperature sensors as well as the cell current and voltage sensors. The complete overview of the operational test cell parameters is observed and controlled from the software interface. Temperatures, pressures, gas flow rates, cell voltage and cell current can be varied by manual inputs from this interface. It is also possible to run user defined scripts for long term trials. Along with hydrogen and air as reactant gases, nitrogen is also supplied as an inert gas, often used for purging remnants of the reactant gases during shut down or start-up phases. The gas flow rates and absolute pressures can be maintained separately for the anode and the cathode. Standard operating conditions are set at $160^{\circ} \mathrm{C}$ temperature, 2.5 bar absolute pressure and anode and cathode flow rates at 0.1 and 0.3 liters per minute respectively.

The electrode-electrolyte interface remains to be the main focus for any improvement in performance of the HT-PEM fuel cell. Figure 1 shows the schematic depiction of the membrane in contact with the electrode (cathode), where both the two phase as well as the three phase boundary reaction zones are formed due to the electrolyte reaching into or partially flooding the porous electrode. The three phase boundary reaction zone is shown to be the contact area where the three phases namely the liquid electrolyte (I), the solid catalyst particle (II) and the air in the gaseous phase (III) are present. Chronoamperometric analyses on fuel cells with such an undefined electrode-electrolyte interface are hardly useful without separating the two phase boundary reaction zone from the three phase boundary reaction zone. For achieving this separation, certain modifications are made by changing the extent of the electrolyte flooding of the electrode, thus resulting into three distinct states of the electrode. These states are depicted in Figure 2 as homogenously distributed Pt/C particles with the different electrolyte flooding. 


\section{Results and Discussion 4.1 Polarization curves}

The steady state behavior of the three modified electrodes can be seen from their $\mathrm{I} / \mathrm{E}$ curves at $160^{\circ} \mathrm{C}$ as shown in Figure 3. The curves for the dry and the regular cell are almost identical. The electrode modifications have no affect on the steady state behavior for these two types. The flooded cell on the other hand shows poor performance throughout. If referred to Figure 2 again, the lower cell current in the flooded cell can be attributed to the absence of the three phase boundary. Since both the dry and the regular cell are assumed to have the same geometric area of the three phase boundary region, the steady state currents are identical over the entire cell voltage range.

As the temperatures are lowered to $120^{\circ} \mathrm{C}$ (Figure 4), the I/E curves for the same cells present a slightly different picture. The flooded cell shows a similar curve as at $160^{\circ} \mathrm{C}$ but the dry cell curve is now quite distinct in comparison to the regular cell. At higher cell voltage and low cell current also known as the activation region, the dry cell shows poor performance. This continues to be the case in the quasi-linear ohmic region, but in the mass transport limitation region the regular cell current drops quite early in comparison. The regular cell current drops below the dry cell at $0.4 \mathrm{~V}$. The boiling point of water at 2.5 bar absolute pressure is around $129^{\circ} \mathrm{C}$. This can make the removal of product water at $120^{\circ} \mathrm{C}$ rather slow when compared to that at $160^{\circ} \mathrm{C}$. Since the regular cell is assumed to have a part of its electrode flooded with electrolyte, further flooding by product water can cause complete flooding and thus induce current losses due to oxygen transport resistances. This however is not the case for the dry cell. Since most of its electrode is expected to be void of the electrolyte, flooding by product water is not as detrimental to its performance at the same voltages.

In Figure 5 the $\mathrm{I} / \mathrm{E}$ curves at $80^{\circ} \mathrm{C}$ show identical behavior of the dry and regular cell in the activation and the ohmic region. But the cell current drop due to mass transport losses is now observed much earlier $(0.5 \mathrm{~V})$ for the regular cell as compared to the dry cell. This is an expected trend due to lowering of temperatures. The dry cell behavior at lower temperatures in the mass transport limitation region has the best performance. Nevertheless, for most fuel cell applications, cell voltages in the range of $0.6 \mathrm{~V}-0.7 \mathrm{~V}$ are favorable and that's where the regular cell has the better cell currents in the investigated temperature range. During the fabrication stage the partial flooding of the regular cell is difficult to quantify. It is seen clearly that this electrode-electrolyte interface plays a crucial role in the fuel cell performance. In the next section, dynamic measurements on three test cells are done via chronoamperometry. The analysis of the recorded transient currents by Cottrell equation provides a possible diagnostic method for characterizing the electrode-electrolyte interface.

\subsection{Reaction Zones}

The chronoamperometric measurements are carried out on the three test cells at $160^{\circ} \mathrm{C}$. In Figure 6 , the left graph shows the transient current recorded when a cell voltage step from OCV to $0.1 \mathrm{~V}$ is applied. The right figure is the corresponding Cottrell plot, where the transient current after the applied voltage step is plotted against the inverse square root of time. The highest peak current is observed for the flooded cell, where maximum platinum catalyst particles are expected to be in contact with the electrolyte. This current however drops rapidly below the currents observed from the other two cells. The regular and the dry cell show almost similar behavior, which was also the case for their polarization curves at $160^{\circ} \mathrm{C}$. However, it is observed here that the cell current peak after the voltage step is higher for the regular cell. This indicates that since the electrolyte in this case floods the electrode more than in the dry cell, more platinum catalyst particles are in 
contact with the electrolyte and therefore electrochemically active. While the steady state behavior shows no such differences for the regular and the dry cell, the dynamic behavior indicates the difference in the electrodeelectrolyte interface.

Similar plots at $120^{\circ} \mathrm{C}$ are shown in Figure 7 . The peak current is the largest for the flooded cell and its Cottrell plot is linear. This straight line heading towards the origin is similar to a planar electrode in the Cottrell experiment. The regular and the dry cell Cottrell plots are more distinct with the peak current of the regular cell larger than that of the dry cell, but the steady state current considerably lower. The chronoamperometric and Cottrell plots at $80^{\circ} \mathrm{C}$ for the three cells are shown in Figure 8. The flooded test cell Cottrell plot is similar to the Cottrell experiment for a planar electrode. It is linear heading towards the origin. This describes the two phase (liquid and solid) boundary reaction zone where the oxygen permeates i.e. dissolves into the electrolyte and diffuses towards the electrode. The slight non linearity in the plot is due to the capacitive current at short times ( 3 $\left.>t^{-1 / 2}>10\right)$.

The dry test cell has a Cottrell plot similar to the spherical electrode with a straight line intercepting the cell current axis. The magnitude of the current for the dry cell is almost five times higher than that of the flooded cell at steady state. This can be attributed to the reaction at the three phase boundary, which requires permeation of oxygen in air, which is much faster than that in the electrolyte. The Cottrell plot decreases until $t^{-1 / 2}=\sim 1$, beyond which a slight increase and then a decrease in cell current in observed. The increase in the cell current is expected to be due to product water, which acts as an extension of the electrolyte in the electrode. This brings previously unused catalyst particles in contact with the electrolyte and therefore slightly increases the active area and also the cell current. For times longer than a couple of seconds, effects other than diffusion (mainly convection) play a significant role and therefore these times on the Cottrell plots (between 0 and 1 on the $\mathrm{x}$-axis) deviate from expected behavior [13].

The regular test cell Cottrell plot shows a larger slope at short times similar to the flooded test cell. This behavior transitions into a slope more like the dry cell at longer times. It is therefore plausible to assume that the regular test cell with sufficient electrolyte forms both, a two phase and a three phase reaction boundary and has a Cottrell plot similar to a combination of the plots of the other two cells. This can be simulated and validated as shown in the section 4.4. The following sections consider the experimental results performed at $80^{\circ} \mathrm{C}$ for further analysis.

\subsection{Electrode Active Area}

The Cottrell equation for the flooded cell, Eq. (2), is used to simulate the Cottrell plot while taking the active electrode area $A$ as an unknown.

$$
i_{d}(t)=\frac{n F A D_{\mathrm{O}_{2}, \mathrm{H}_{3} \mathrm{PO}_{4}}^{1 / 2} C_{\mathrm{O}_{2}, \mathrm{H}_{3} \mathrm{PO}_{4}}^{*}}{\pi^{1 / 2} t^{1 / 2}}
$$

The oxygen diffusion coefficient in phosphoric acid, $D$ and initial concentration in phosphoric acid $C^{*}$ are obtained by other ex-situ experiments (see Table 1) and have similar magnitude to the data reported in literature [14]. This equation is applied only to the relevant measurement data points, i.e., the intermediate measured points. The shorter times that have a large influence from cell capacitance and the times longer than 1 second are neglected for this analysis. This is depicted in Figure 9 where one sees the simulated line being linear heading towards the origin in good agreement with the measurement data at intermediate measured points. The active electrode area is the only unknown in this equation and is estimated for these measured data points to be approximately $3500 \mathrm{~cm}^{2}$. As the platinum particles used in electrode preparation have an average weight specific surface area of $500 \mathrm{~m}^{2} \mathrm{~g}^{-1}$, the maximum possible surface area based on Pt loading of the catalyst in the cathode is estimated to be around $7000 \mathrm{~cm}^{2}$ per $\mathrm{cm}$ geometric area. Even in case of the flooded cell, not all catalyst particles are accessible by the electrolyte. This estimation suggests that approximately $50 \%$ of the platinum surface area is not available for reaction. This can be due to loss of catalyst particles in the porous carbon support, sintering and other agglomeration effects.

The non-linearity due to cell capacitance is now taken into account by adding the $2^{\text {nd }}$ term, Eq. (4).

$$
i_{\text {Flooded }}(t)=\frac{n F A D_{O_{2}, H_{3} P_{4}}^{1 / 2} C_{O_{2}, H_{3} P O_{4}}^{*}}{\pi^{1 / 2} t^{1 / 2}}+\frac{E}{R_{u}} \exp \left(\frac{-t}{R_{u} C_{d}}\right)
$$

For the second term, the magnitude of the cell voltage step $E$ is a known value, whereas the cell capacitance $C_{d}$ and uncompensated resistance $R_{u}$ are unknown. The two time dependent terms share no common parameters. The double layer capacitance obtained from this equation is approximately $0.0875 \mathrm{~F}$ and the uncompensated resistance value of $0.64 \mathrm{Ohms}$. The solution for this equation with the estimated values of $C_{d}$ and $R_{u}$ also shows good agreement with the measurement points as shown in Figure 9.

This approach can be used as a comparative analysis for estimating the maximum available catalyst area in commercial electrodes. The estimated double layer capacitance is due to the entire $\mathrm{Pt} / \mathrm{C}$ area in contact with the electrolyte. However, the contribution to the cell current at the intermediate measurement points used to estimate 
the active platinum area has negligible influence from the capacitive current and therefore the estimated active area is expected to be the active platinum catalyst area,

\subsection{Thin Film Boundary}

The Cottrell plot of the dry cell can be simulated using Eq. (3). In this equation, the first time dependent term has the unknown active electrode area $A$ and the second time independent term has the radius of the spherical electrode $\delta$. While the test cell electrode is in no sense spherical, one can treat this parameter as a shape factor. Even though it's difficult to describe this theoretical radius in the context of a porous electrode, its inclusion in the second time independent constant term serves only to ascertain the magnitude of the intercept on the cell current axis. This shape factor therefore has no effect on the slope of the curve, which holds the permeability parameters and the active electrode area.

The three phase boundary reaction zone assumes the oxygen diffusion coefficient and initial concentration are that in air. This input however estimates an active electrode area around $0.6 \mathrm{~mm}^{2}$, which is much smaller than the geometrically projected area $\left(\sim 1 \mathrm{~cm}^{2}\right)$ of the test cell and therefore an improbable scenario. An alternative to the simple three phase boundary reaction zone model is the thin film boundary model as seen in Figure 10. Similar model approaches are widely reported in the literature for describing active catalyst regions in a Nafion based PEM fuel cell [16 - 18]. In the presented case the catalyst particle are covered by a thin film of the electrolyte and the oxygen which diffuses through the air has to first dissolve in the electrolyte film in order to reach the reaction site. An important assumption here is that the thickness of the electrolyte film is extremely small and all the dissolved oxygen molecules are directly available for reaction on the catalyst surface. This is in agreement with the work done by Bjerrum et al [15]. Here, the thickness of the phosphoric acid film on electrodes was estimated to be $0.1 \mu \mathrm{m}$ order of magnitude. With this consideration, the diffusion of the dissolved oxygen molecule to the active site within the electrolyte thin film can be neglected and only the diffusion of oxygen in air is considered to be rate limiting. The initial concentration of oxygen is however that in the electrolyte itself and not in air. The diffusion term can be accordingly modified as shown here.

$$
i_{\text {Dry }}(t)=\frac{n F A D_{O_{2}, A i r}^{1 / 2} C_{O_{2}, H_{3} P O_{4}}^{*}}{\pi^{1 / 2} t^{1 / 2}}+\frac{n F A D_{O_{2}, A i r} C_{O_{2}, H_{3} P O_{4}}^{*}}{\delta}
$$

In this equation, the initial concentration of oxygen in air is thereby replaced with the initial concentration of oxygen in phosphoric acid and the model estimates an active electrode area of about $3 \mathrm{~cm}^{2}$. The simulation is in close agreement with the experimental data as seen for the dry cell in Figure 11. As seen in the Cottrell plots for all three cells at $80^{\circ} \mathrm{C}$, the steady state current for the dry cell is five times larger than that for the flooded cell. Thus it can be concluded that a much smaller active electrode area with fast oxygen transport in the dry cell can account for a larger cell current when compared to a much larger active electrode area but slow oxygen transport in the flooded cell. A build up of such a thin film boundary in the electrode-electrolyte region can therefore determine the performance of the fuel cell.

\subsection{Commercial Electrode Behavior}

Even though the dry cell performs extremely well at low temperatures in the mass transport limitation region, the cell current at working voltages of $0.6 \mathrm{~V}-0.7 \mathrm{~V}$, the regular cell performs consistently better in the tested temperature range. This goes to show that a certain degree of partial flooding is important for power generation. However, quantifying such a character of the electrode-electrolyte interface after a commercial fuel cell is assembled is not a trivial task. The Cottrell plot of the regular cell (commercial electrode) can be considered to be combination of the flooded and dry cell plots. Therefore it is possible to add the Cottrell equations for the flooded and dry cells along with an additional transition term to be able to describe the standard cell. One such extension has been presented in the works of S. Mitsushima et al [19], which was validated for a platinum microelectrode.

$$
i_{d}(t)=\frac{n F A D_{O_{2}}^{1 / 2} C_{O_{2}}}{\pi^{1 / 2} t^{1 / 2}}+\frac{n F A D_{O_{2}} C_{O_{2}}}{r_{0}}+\frac{n F A D_{O_{2}} C_{O_{2}}}{r_{0}}\left(0.273 \exp \frac{-0.3911 r_{0}}{D_{O_{2}}^{1 / 2} t^{1 / 2}}\right)
$$

This equation is an extension of the Cottrell equation with the first term representing the flooded part, the second term accounting for the intercept on the current axis and the third term, which contains the exponential time dependence. The diffusion coefficient and initial solubility of the oxygen is in the electrolyte. The third term is a product of the current intercept (second term) and the exponential time dependent term with the preexponential and exponential constants (positive 0.2732 and negative 0.3911 ). The term $r_{0}$ in this equation is the electrode radius and is analogous to the term $\delta$ used in all previous equations. The exponential term presented in this work is rather empirical in nature, but can be used to describe the transition of the Cottrell plot from the flooded cell behavior to the dry cell behavior. 
In case of the standard cell, the electrode is partially flooded along with the thin film boundary. For the Cottrell plot, that would mean partial contribution from the flooded cell equation term and full contribution from the dry cell equation term assuming a similar thin film boundary area. The short time influence of the flooded cell term, which transcends into the long time influence of the dry cell term, is sufficiently connected by the exponential term of the equation. This can be written as:

$i_{\text {cell }}(t)=x i_{\text {Flooded }}+i_{\text {Dry }}+\frac{n F A D_{O_{2}, A i r}^{1 / 2} C_{O_{2}, H_{3} P O_{4}}}{\delta}\left(P \exp \frac{Q . r_{0}}{D_{O_{2}}^{1 / 2} t^{1 / 2}}\right)$

In this equation the unknown parameters are $x, P$ and $Q$, where $x$ is the extent of flooding of the regular cell ranging between zero for a dry cell to one for a flooded cell. The parameter $P$ and $Q$ are left completely free to be solved to match the experimental measurements and the result is shown in Figure 11. The estimated value of parameter $x$ is found to be 0.6 and those of $P$ and $Q$ are 1.3808 and -0.5979 respectively. The empirical constants $P$ and $Q$ have no physical significance, but when compared with Eq. 8 for the microelectrode, one can observe the increase in magnitude for both as well as maintaining the negative sign for constant $Q$. The value of $x$ signifies the contribution of the flooded cell equation to the regular cell current equation. This technique shows the estimation of flooding of the electrode by the electrolyte in a commercial fuel cell.

\section{Conclusions and Outlook}

Chronoamperometric testing and Cottrell analysis performed on commercial electrodes give valuable insights into its electrode-electrolyte interface. This interface is experimentally and analytically described using the combination of the two extreme cases of electrode flooding. Polarization curves as well as Cottrell plots of the three test electrodes show very distinct behavior. The flooded cell analysis provides a new possibility to estimate the maximum available catalyst area in a commercial HT-PEM fuel cell. The formation of the thin film boundary layer in the electrode that determines largely the output of the cell can be seen from the dry cell analysis. A certain level of "floodedness" of the electrode is necessary to maximize the cell performance under typical fuel cell operating conditions as seen from the performance of the regular cell. This approach can be a useful diagnostic method for characterizing MEAs postproduction. Finally, the estimation of maximum active area available in the electrode is a motivation for further optimization of platinum usage for important cost reductions in commercial electrodes.

\section{Acknowledgements}

The authors are thankful to B. Schaar at the Volkswagen AG and U. Krewer at the Max Planck Institute, Magdeburg, for their valuable contribution to the discussion. Also the authors are grateful for the support extended by O. Groeger, G. Huebner, J. Huslage and F. Seyfried at the Volkswagen AG.

\section{List of Symbols}

Latin letters

$\begin{array}{ll}\mathrm{A} & \text { Active electrode area } / \mathrm{m}^{2} \\ \mathrm{C}^{*} & \text { Initial bulk concentration } / \mathrm{mol} \mathrm{m}^{-3} \\ \mathrm{C}_{\mathrm{d}} & \text { Double layer capacitance } / \mathrm{F} \\ \mathrm{D} & \text { Diffusion coefficient } / \mathrm{m}^{2} \mathrm{~s}^{-1} \\ \mathrm{E} & \text { Cell potential magnitude } / \mathrm{V} \\ \mathrm{F} & \text { Faraday constant } / \mathrm{C} \mathrm{mol}^{-1} \\ \mathrm{i} & \text { Current } / \mathrm{A} \\ \mathrm{n} & \text { Number of electrons transferred } \\ \mathrm{P} & \text { Pre-exponential constant } \\ \mathrm{Q} & \text { Exponential constant } \\ \mathrm{r}_{0} & \text { Electrode radius / cm } \\ \mathrm{Ru} & \text { Uncompensated resistance / } \Omega \\ \mathrm{t} & \text { Time / s } \\ \mathrm{X} & \text { Fraction of flooded electrode } \\ \mathrm{Greek} \text { letter } & \\ \delta & \text { Electrode radius, shape factor } / \mathrm{cm}\end{array}$

\section{References}

[1] Fuel Cells Bulletin 2008, Vol. 2008, Issue 1, 3.

[2] Fuel Cells Bulletin 2007, Vol. 2007, Issue 6, 2.

[3] Fuel Cells Bulletin 2004, Vol. 2004, Issue 4, 5.

[4] Fuel Cells Bulletin 2004, Vol. 2004, Issue 6, 10. 
[5] D. Cheddie, N. Munroe, Energy Conversion and Management 2006, 47, 1490.

[6] D. Cheddie, N. Munroe, J. Power Sources 2006, 156, 414.

[7] P. Zelenay, B. R. Scharifkar, J. O’M. Bockris, D. Gervasio, J. Electrochem. Soc.: Electrochemical Science and Technology 1986, 2262.

[8] A. J. van Stroe, L. J. J. Janssen, Anal. Chim. Acta 1993, 279, 213.

[9] T. Nishiumi, M. M. Abdul, K. Aoki, Electrochem. Commun. 2005, 7, 1213.

[10] J, Jiang, A, Kucernak, J. Electroanal. Chem 2004, 567, 123.

[11] D. Gerteisen, T. Heilmann, C. Ziegler, J. Power Sources 2008, 177, 348.

[12] H. Weydahl, S. Møller-Holst, G. Hagen, B. Børresen, J. Power Sources 2007, 171, 321.

[13] A. J. Bard, L.R. Faulkner, Electrochemical Methods: Fundamentals and Applications, Wiley, 2001, pp. 156.

[14] Z. Liu, J. S. Wainright, R. F. Savinell, Chem. Eng. Sci. 2004, 59, 4833.

[15] 1. Quingfeng, X. Gang, H. A. Hjuler, R. W. Berg, N. J. Bjerrum, J. Electrochem. Soc 1986, 141,3114.

[16] Q. Wang, D. Song, T. Navessin, S. Holdcraft, Z. Liu, Electrochim. Acta 2004, 50, 725.

[17] R. Madhusudana Rao, R. Rengaswamy, J. Power Sources 2006, 158, 110.

[18] Y. Bultel, P. Ozil, R. Durand, Electrochim. Acta 1998, 43, 1077.

[19] K. Ota, S. Mitsushima, in Handbook of Fuel Cells, Volume 2, Electrocatalysis (Eds. W. Vielstich, A. Lamm, H. Gasteiger), Wiley, 2003, 483.

\section{Figure Captions}

Fig. 1 Reaction zones: depiction of two phase and three phase boundary

Fig. 2 Schematic representation of the modified electrodes

Fig. 3 Polarization curves for the three electrodes at $160^{\circ} \mathrm{C}$

Fig. 4 Polarization curves for the three electrodes at $120^{\circ} \mathrm{C}$

Fig. 5 Polarization curves for the three electrodes at $80^{\circ} \mathrm{C}$

Fig. 6 Transient current responses at $160^{\circ} \mathrm{C}$ and corresponding Cottrell plot

Fig. 7 Transient current responses at $120^{\circ} \mathrm{C}$ and corresponding Cottrell plot

Fig. 8 Transient current response at $80^{\circ} \mathrm{C}$ and corresponding Cottrell plot

Fig. 9 Cottrell plot and simulation results for flooded cell current

Fig. 10 Schematic depiction of a thin film boundary reaction zone model

Fig. 11 Cottrell plot and simulation results for dry cell and regular cell current 


\section{Tables}

Table 1 Modeling parameters used in and obtained from simulations (for $80^{\circ} \mathrm{C}$ ).

\begin{tabular}{|c|c|c|c|}
\hline & \multicolumn{2}{|c|}{ Modified Electrodes } & \\
\hline Model input (output) Parameters & Flooded Cell & Dry Cell & Regular Cell \\
\hline $\begin{array}{l}\text { Diffusion coefficient of oxygen in } \\
\text { electrolyte, } \mathrm{D} / \mathrm{cm}^{2} \mathrm{~s}^{-1}\end{array}$ & $2.2 * 10^{-6}$ & - & $2.2 * 10^{-6}$ \\
\hline $\begin{array}{l}\text { Diffusion coefficient of oxygen in air, } \\
\mathrm{D} / \mathrm{cm}^{2} \mathrm{~s}^{-1}\end{array}$ & - & 0.274 & 0.274 \\
\hline Active electrode area, $\mathrm{A} / \mathrm{cm}^{2}$ & 3500 (output) & 3 (output) & $\begin{array}{c}3500 \text { (input for flooded cell term) } \\
3 \text { (input for dry cell term) }\end{array}$ \\
\hline Cell potential magnitude, E / V & 0.9 & 0.9 & 0.9 \\
\hline $\begin{array}{l}\text { Initial concentration of oxygen in } \\
\text { electrolyte, } \mathrm{C} / \mathrm{mol} \mathrm{cm}^{-3}\end{array}$ & $2.5 * 10^{-6}$ & $2.5 * 10^{-6}$ & $2.5 * 10^{-6}$ \\
\hline Extent of flooding, $\mathrm{x} / \mathrm{-}$ & - & - & 0.61 (output) \\
\hline Pre exponential constant, $\mathrm{P} /$ - & - & - & 1.3808 (output) \\
\hline Exponential constant, Q / - & - & - & -0.5979 (output) \\
\hline Double layer capacitance, $\mathrm{C}_{\mathrm{d}} / \mathrm{F}$ & 0.0875 (output) & - & - \\
\hline Uncompensated resistance, $\mathrm{R}_{\mathrm{u}} / \mathrm{Ohm}$ & 0.64 (output) & - & - \\
\hline
\end{tabular}




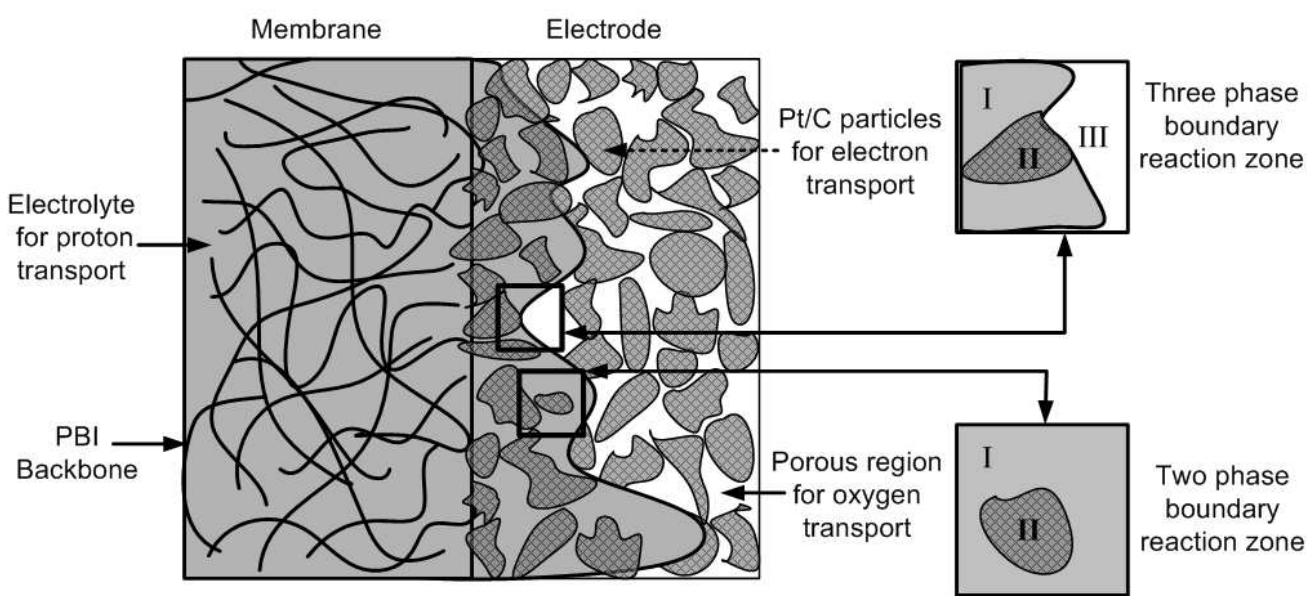

Fig. 1 Reaction zones: depiction of two phase and three phase boundary $266 \times 120 \mathrm{~mm}(96 \times 96$ DPI) 

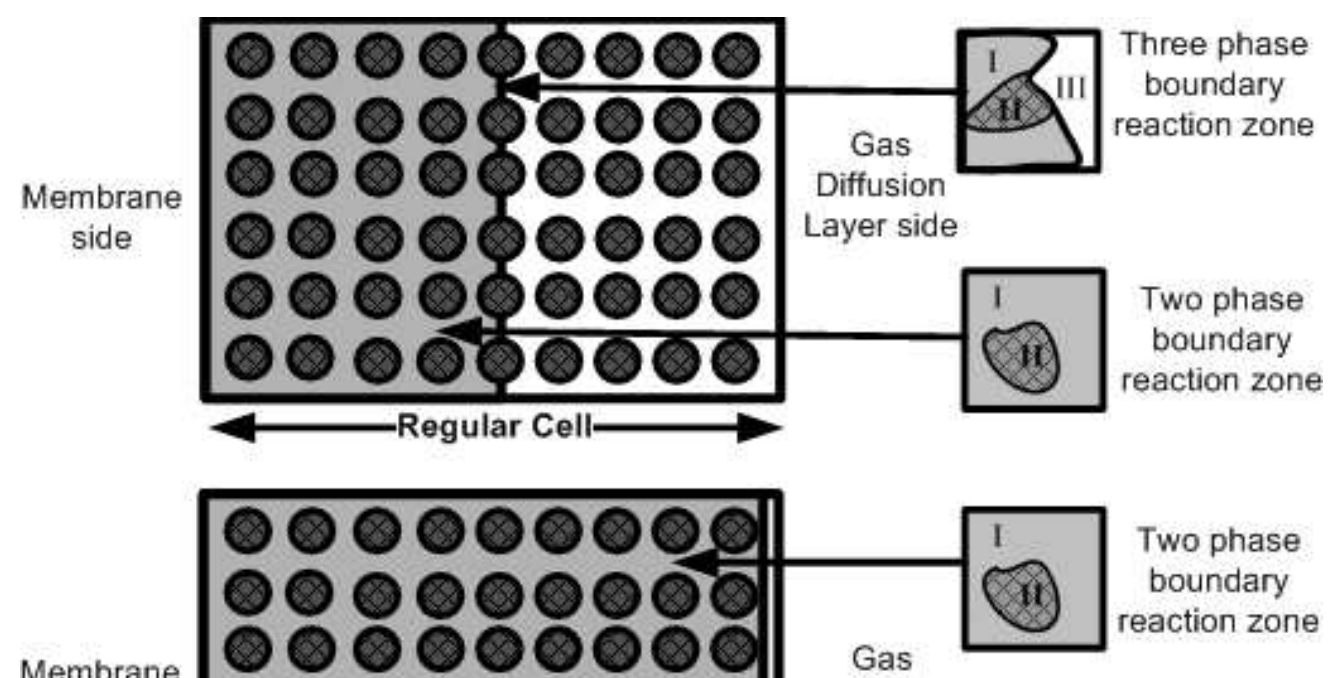

Membrane side

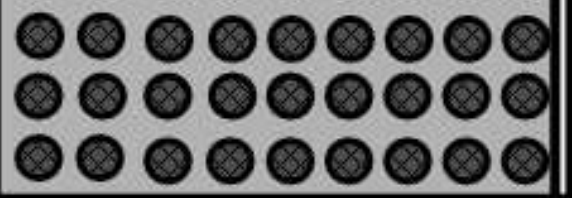

Diffusion

Layer side

Membrane side

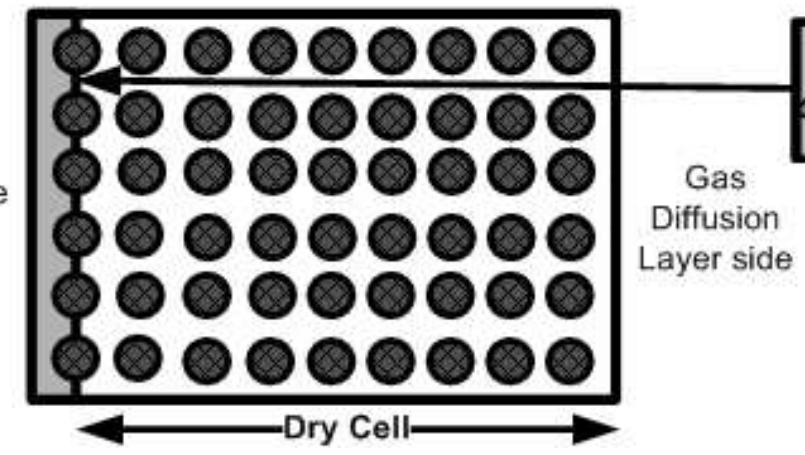

Fig. 2 Schematic representation of the modified electrodes $136 \times 146 \mathrm{~mm}(96 \times 96 \mathrm{DPI})$ 
2

3

4

5

6

7

8

9

10

11

12

13

14

15

16

17

18

19

20

21

22

23

24

25

26

27

28

29

30

31

32

33

34

35

36

37

38

39

40

41

42

43

44

45

46

47

48

49

50

51

52

53

54

55

56

57

58

59

60

Fig. 3 Polarization curves for the three electrodes at $160^{\circ} \mathrm{C}$ $104 \times 82 \mathrm{~mm}(600 \times 600$ DPI $)$ 
Fig. 4 Polarization curves for the three electrodes at $120^{\circ} \mathrm{C}$ $104 \times 82 \mathrm{~mm}(600 \times 600 \mathrm{DPI})$ 
Fig. 5 Polarization curves for the three electrodes at $80^{\circ} \mathrm{C}$ $104 \times 82 \mathrm{~mm}(600 \times 600 \mathrm{DPI})$ 


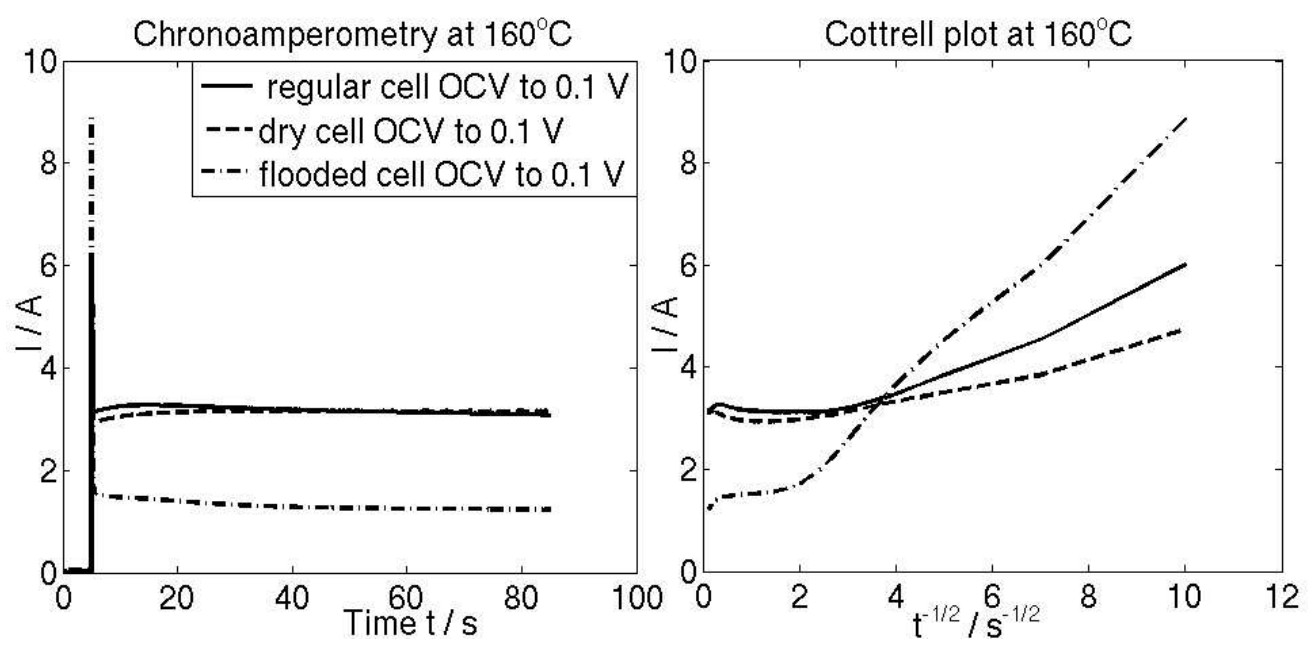

Fig. 6 Transient current responses at $160^{\circ} \mathrm{C}$ and corresponding Cottrell plot $271 \times 134 \mathrm{~mm}(90 \times 90 \mathrm{DPI})$ 

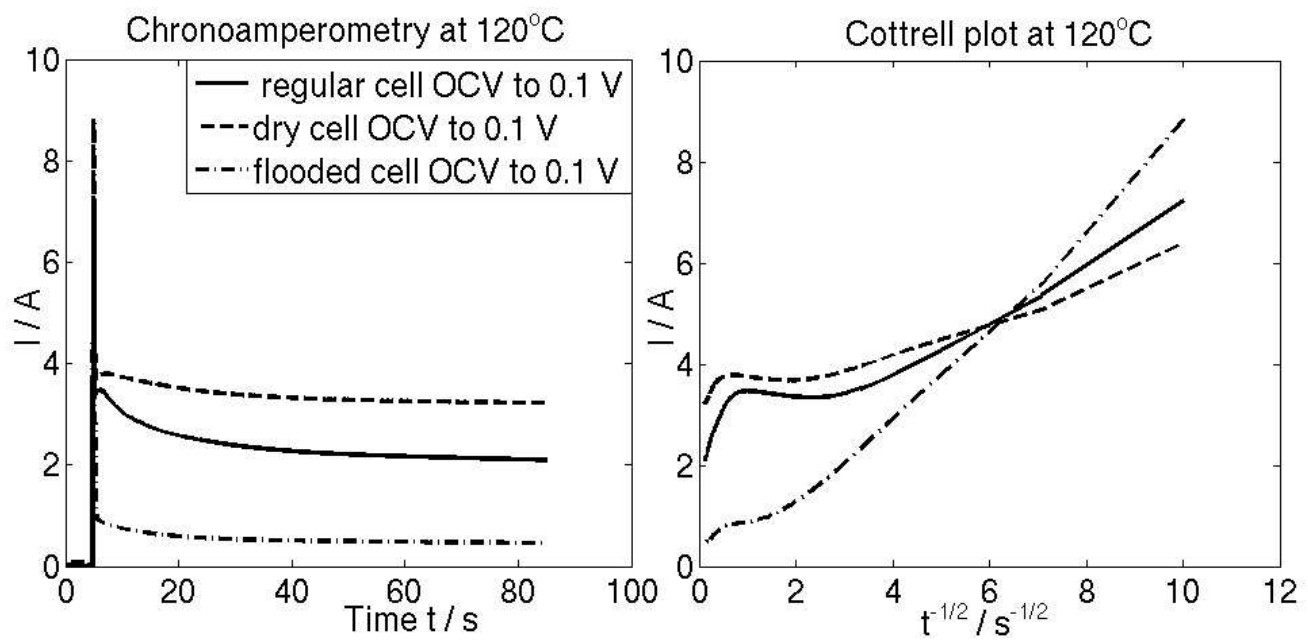

Fig. 7 Transient current responses at $120^{\circ} \mathrm{C}$ and corresponding Cottrell plot $271 \times 134 \mathrm{~mm}(90 \times 90 \mathrm{DPI})$ 


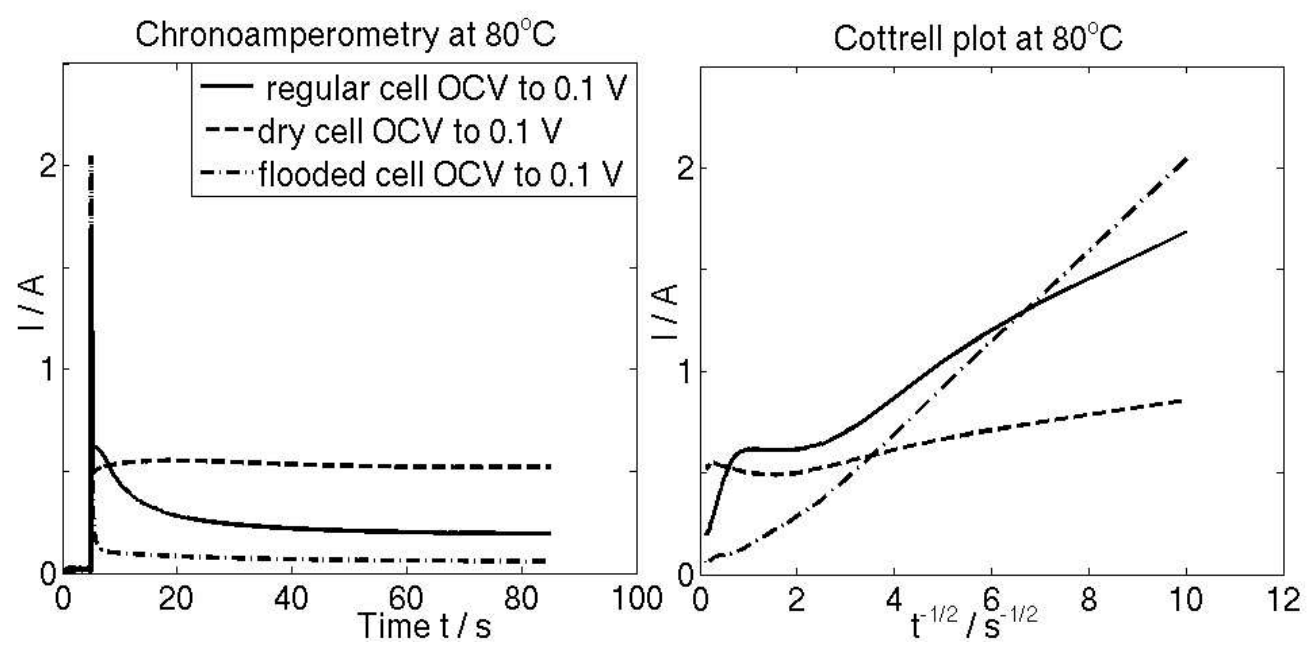

Fig. 8 Transient current response at $80^{\circ} \mathrm{C}$ and corresponding Cottrell plot $271 \times 134 \mathrm{~mm}(90 \times 90 \mathrm{DPI})$ 


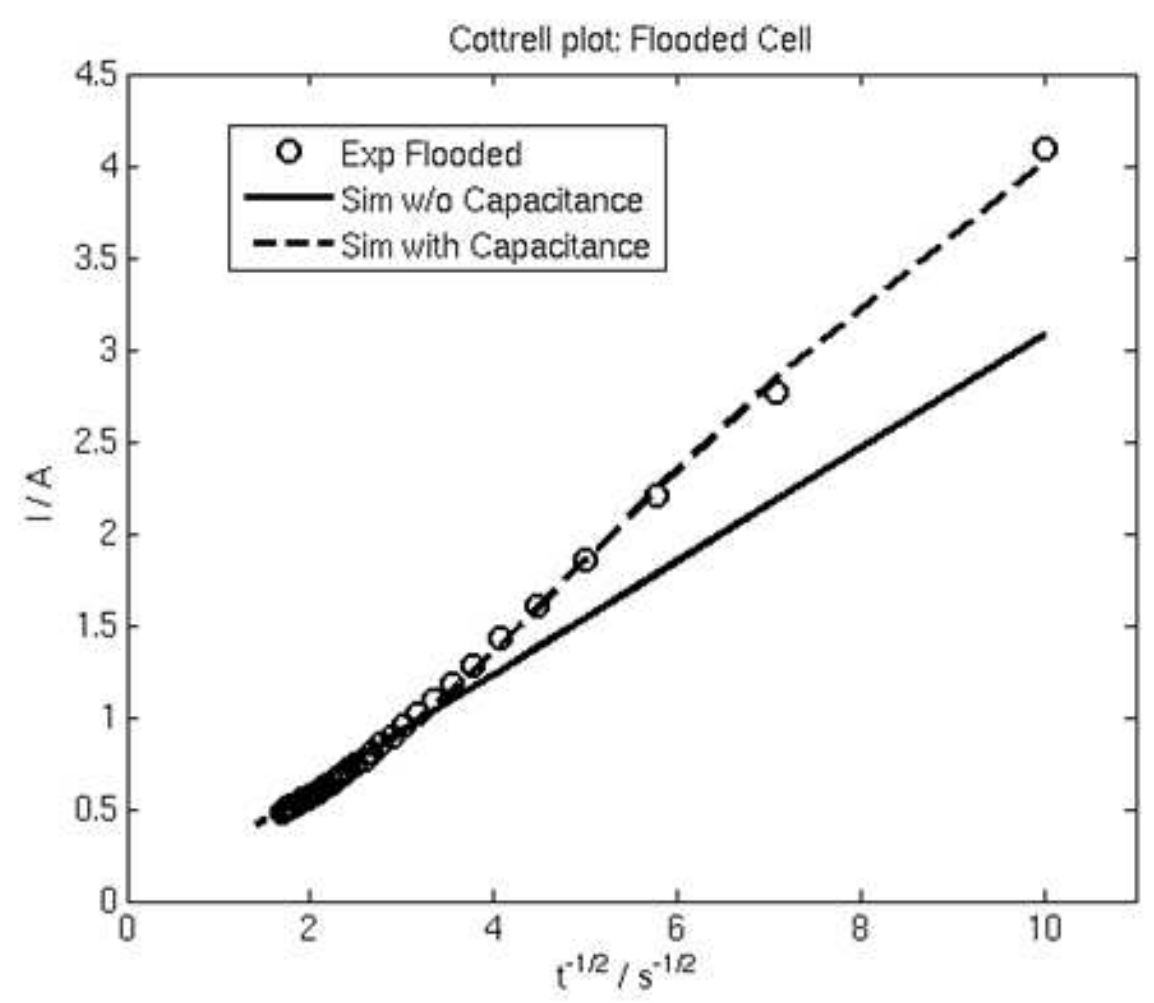

Fig. 9 Cottrell plot and simulation results for flooded cell current $134 \times 105 \mathrm{~mm}(96 \times 96 \mathrm{DPI})$ 


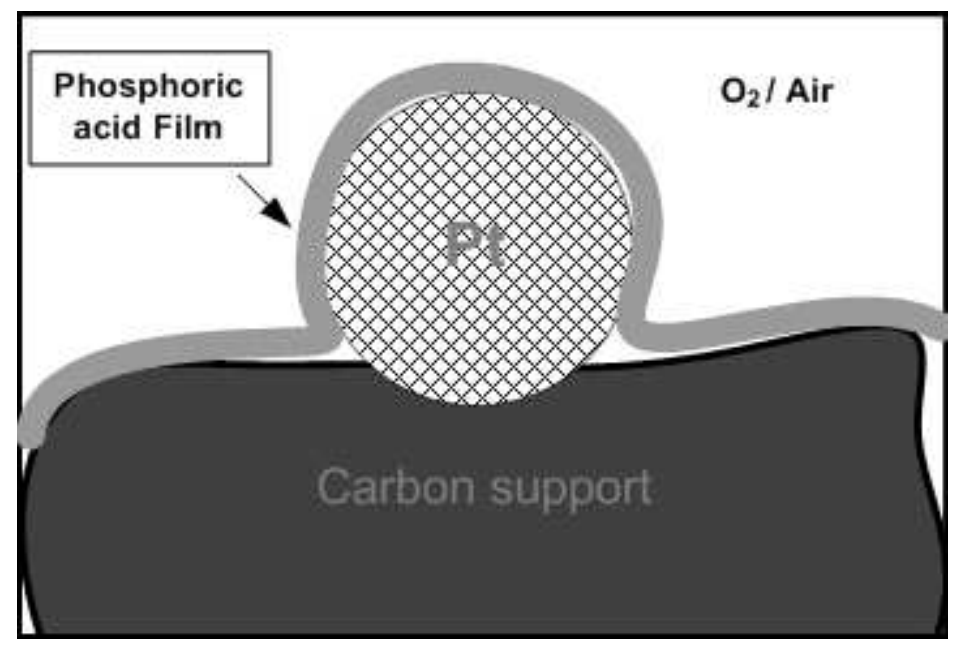

Fig. 10 Schematic depiction of a thin film boundary reaction zone model $94 \times 63 \mathrm{~mm}(96 \times 96 \mathrm{DPI})$ 
Fig. 11 Cottrell plot and simulation results for dry cell and regular cell current $104 \times 82 \mathrm{~mm}(600 \times 600 \mathrm{DPI})$ 